\title{
Taxation of professional team sport athletes in the Czech Republic 1
}

\author{
Michal Radvan*, Jan Neckáŕ**
}

* JUDr. Michal Radvan, PhD. is associate professor for Financial Law, specialized in tax law and local government finance. $\mathrm{He}$ is the author of 5 books and the co-author of almost 40 books. $\mathrm{He}$ presented his scientific research in approx. 70 reviewed articles in prestigious journals and conference proceedings. He is a member of European Association of Tax Law Professors and Information and Organization Centre for the Research on the Public Finances and Tax Law in the Countries of Central and Eastern Europe. (e-mail: michal.radvan@law.muni.cz)

** Mgr. Jan Neckáŕ, PhD. Masaryk University, Faculty of Law, specialized in tax law. (e-mail: janeckar@seznam.cz)

Abstract: The career of a professional athlete is unique when compared to other professions. Not purely the role and nature of the position (such as whether they are individual or team players), but also from the factual, legal, and especially tax perspectives. And since a professional athlete's income is subject to taxation, it is necessary that their activity is accurately determined for appropriate tax assessment. The main purpose of this article is to examine the taxation of income on professional athletes in team sports. Our study is based on case law determined by the Czech Republic's Supreme Administrative Court (hereinafter 'Supreme Administrative Court'), $\underline{2}$ which determined that it is necessary to tax the activities of team players as income from self-employment. The existing scientific literature on this subject in the Czech Republic is not particularly relevant, as it is mostly descriptive. $\underline{3}$ International scientific literature is more abundant and comprehensive, such as noted publications by Tetłak, $\underline{4}$ Simpson, 5 and Taxation of Artistes and Sportsmen in International Tax Law, edited by Loukota and Stefaner. $\underline{6}$

Keywords: tax; tax assessment; professional athletes; self-employment

\section{Characteristics of team player activity}

The performance of a team player is largely determined by club rules and regulations in which his or her activity is performed. This differs considerably from the abilities of an individual athlete. Individual professional athletes (i.e. tennis players, boxers, etc.)7_ act on his or her own behalf and exhibit a great deal of agency in the decision-making process. He or she chooses which tournament(s) to play and with what frequency, he or she may be paid by several subjects (usually by the organizer of a sporting event), he or she bears the costs of hiring a coach, massage therapist(s), servicemen, and other people on his or her team, he or she chooses when and where they train, etc.

In contrast, team players (such as hockey, football, basketball players, etc.) are in a relationship only with one subject: the club in which they perform their activity. They do not act on their behalf nor in their own personal 
interest, but only as members of a team or club. It is the leadership of the club who determines all functional duties, such as who participates in a specific competition, if a player is transferred during the season (with or without the player's consent), training, following a dietary regime, and other decisions that affect players. Furthermore, team players cannot usually influence who the club hires for coaching staff or the service team. Instead, team players must abide by regulations set forth by the leadership and their coaches. It is paradoxical that the more competitive a team becomes, the more it relies on the performance of its individual players-players who do not participate in the club's decision-making processes.

In some European countries, it is quite common that team players are employees of the club. In the Czech Republic however, professional team players (for all sports, not solely football) are self-employed. $\underline{8}$ The player and the club agree on a so-called 'professional contract' which is considered an innominate contract in the Czech legal order.9 Professional contracts include mutual rights and obligations of the player and the club. Some kind of a model contract is included in the Directive on the Evidence of Professional and NonAmateur Contracts approved by the Executive Committee of the Football Association of the Czech Republic.10 This is somewhat contradictory to the notion of self-employment in team sports, because the first article states that, 'in accordance with the professional contract the player performs the sports activity as his or her main employment', which would indicate a dependent activity. However, according to the model professional contract for football, 11 in the area of income tax, social and health security, the player is considered to be self-employed in accordance with Art. 7 par. 2b) of the Income Tax Act $\underline{12}$ and his or her income arising from this contract is the income from independent employment, which is neither a profession based on a license nor entrepreneurship under special regulations'. It is important to note that similar contracts are implemented for other team sports, however any provision of this type in a private contract is, for the purpose of public tax law, irrelevant.

One element regarding the taxation of team player's income that is repeatedly discussed is the different rate of income taxation if the athlete taxes his or her income from employment, or self-employment. From a tax perspective team players consider themselves as self-employed because it is mutually favorable for themselves and the clubs. Athletes receive an undeducted fee, and it is their obligation to complete tax returns, and pay taxes 
including social and health security. This obligation is therefore not on, all of which is not required for the club. This also enables the players to make deductions from their incomes costs, which they spend in accordance with their activity, something that is not possible with the taxation of employees. Any costs related to their employment can be deducted. This could include the washing of uniforms (although this is done by the club), cost for travel to European cup matches, 13 food to maintain their diet, accommodation, trips for training, and any additional costs incurred as they relate to a player's position as a member of the club's team.

The activity of a professional team player is unique, so it is not possible to apply (without limitations) all institutes of labor laws guaranteed by the Labor Act. One of the main areas for potential disputes that may arise is the possibility of a one-way termination of the employee (the player) from the club without any reason given. In this instance, a player could change clubs without receiving compensation. Additional potentially problematic issues include working hours, overtime and obligatory breaks at work, as well as limitations set for the conclusion of fixed-term employment contracts. $\underline{14}$

The activity of professional athletes, while not expressly excluded from entrepreneurship by the Trade Licensing Act, 15 . cannot be subordinated under permitted professional or unqualified trade (and neither as an independent profession). Many athletes (as well as sports clubs) consider relations arising out of the so-called professional contracts to be of a self-employed nature, and income arising out of these contracts is also considered income from selfemployment. The basis for this opinion is from a commonly known ruling of the Supreme Administrative Court from 2011. $\underline{16}$

\section{Taxation of professional athletes' income}

The terminology which defines the relationship between the player and the club are not essential regarding taxation of team players' income. It is necessary to determine the characteristics of the player's activity and its subordination under particular provisions of the Income Tax Act. Two basic types of incomes shall now be examined: income from employment, and income from selfemployment. 
Income from self-employment includes, among other things, income from trade, other types of business, and from an independent profession. In all of these cases, it is presumed that the player performs, and is responsible for, an independent activity. However, the team player cannot fulfill this requirement because he or she does not perform on his or her behalf, and does not make independent decisions. His or her income received from the club (whether it is for individual matches, in the form of a regular fee for his or her sport, or other performance in favor of the club) cannot be considered as income from self-employment, and the tax payer is not entitled to deduct from this income the relevant costs spent to reach, secure, and maintain the income, nor is he or she entitled to apply lump costs. However, income from advertising activities of the individual player, for example, which are not connected to his or her activity for the club, could be taxed as income from self-employment.

Income from employment includes payment in the form of an income from present or past employment and similar relationships, in which the tax payer performing the activity for the employer must complete the orders of the employer. In 2005, the Supreme Administrative Court dealt with these terms with the emphasis on the nature of a relationship similar to employment and similar relationships.17_ It stated that a similar relationship is a relationship which is not an employment and similar relationships, but which in its nature and role responds to the stated relationships, that means that its main characteristics are the same as with these relationships. Common to employment and similar relationships is firstly that it is a legal relationship, usually of a private nature but also of a public nature (typically an official relationship)... When examining whether the given relationship can be subordinated under the term 'similar relationship', it is always necessary to examine its actual content intended and wanted by the participants, especially if the participants pretend something different than what is the actual content of their legal relationship. The Court emphasized the principle of material justice, resp. the principle of content priority. When closing the so-called professional contract, it is not important what the title of the contract is and under which legal provisions it was made, but what is its content and what are the rights and obligations of the parties.

Another important feature of employment and similar relationships considered by the Supreme Administrative Court is the relationship of a 'longterm character', determined by whether employment is not completed on a 
one-time basis by fulfilling a certain obligation. So-called professional contracts also fulfill this definition since they are often concluded for the term of one to five years.

Another significant feature of employment and similar relationships not only considered by the Supreme Administrative Court is the fact that the person who provides a certain performance is obliged to follow the orders of the person to whom he or she is bound by the employment contract. This obligation must be explicit, i.e. it must be written into the legal relationship between both participants. For example, under the model professional contract, a football player is obliged to fulfill assignments and orders of coaches during training, at training camps, and of course during matches. 18 For his or her performance, the player receives a fee, usually monetary.

It is without a doubt that the so-called professional contracts in the area of team sports fulfill cumulatively all signs of a relationship similar to an employment and other similar relationships, and therefore a team player's income should be taxed as income from employment.

The term 'dependent activity', was determined by the Supreme Administrative Court in its previous ruling.12 It stated that in order to be considered as a 'dependent activity', a person cannot only perform an activity according to relevant orders, but it must be an activity truly dependent on the employer. The definition of dependency shall be given by the nature of the performed activity (typically performed at one place exclusively for one employer). It shall also be a long-term activity, and the employment relationship shall be made in favor of the person performing the activity. It is also important to note that athletes do not perform their activities in one place. However, it is necessary to consider the text of this ruling as somewhat inaccurate since undoubtedly many more activities exist with noticeable worker mobility. On the other hand, it is necessary to emphasize the section which relates to one employer. Especially with team players, it is unimaginable that a hockey player, for example, would play in one round of a long-term competition in more than one match for one club.

Incomes of team players received from the club are undoubtedly taxed as income from employment 20 because the relationship between the player and the club cumulatively fulfills all signs of a relationship similar to employment and other similar relationships. Partial tax base is the income from employment increased by the amount equivalent to social security and 
contribution for state employment policy and health insurance, which the club, as the employer, is obliged to pay from these incomes.

\section{Conclusion}

The oft-discussed, and media favored 'sport tax' ruling of the Supreme Administrative Court21 is not completely without fault. The Court paid attention mainly to the relationship between the player and the club, but sidelined issues regarding taxation of an athlete's income. The purpose of this article is not to determine the relationship which exists, or should exist, between the player and the club. We agree with the Supreme Administrative Court, that the application of labor law to the area of legal relationships between clubs and players is difficult, and if not in some cases (holiday, transfers etc.), impossible.

Whatever professional contract is agreed upon between the player and the club, it is always necessary for the purpose of taxation of a players' income in accordance with the principle of material justice to examine the contents of this relationship - rights and obligations of the parties. In most cases are these are for contracts over a long period of time (one to five years), in which the athlete (tax payer) is obliged to follow orders of the club (employer). He or she receives a fee for his or her performance, he or she cannot play for more than one club, etc. The so-called professional contracts of athletes in the area of team sports cumulatively fulfill all signs of relationships similar to employment, and therefore should be taxed as income from employment. Shall the taxation of players' income from self-employment be accepted, disguised labor relationships, made for the purpose of the unlawful lowering of tax burden, would be de facto legalized. 22

It shall also be stated that not all players' income necessarily comes from the club.23 The player may have entered into other contracts, for example sponsor contracts, the income from which would be usually taxed under income from self-employment. This is often the case internationally, as Zika, the football agent states: '...the player receives some money from the employment agreement. And then he has another contract, for example a sponsor contract, and he receives much more money through this other contract.'24 It is apparent from the Spanish case of the Argentinian football player Messi, that even here should the financial administrative authority examine the content of 
the legal relationship for determining the income to the right partial legal base. 25 .

It would be appropriate to add that individual athletes (athletes in individual sports such as tennis players) tax their income under partial tax base from self-employment (given that they are not employed by the Ministry of Defense or Ministry of Internal Affairs), because apart from team players, they fulfill the conditions in Art. 7 of the Income Tax Act.

For the purpose of taxation of team player's income it is not necessary, in contrast to the opinion of the Supreme Administrative Court, to pass an adequate legal norm of their activity which would properly take into consideration the specifications of professional athletes. It is apparent from the abovementioned text, that even the regulation de lege lata makes it possible to enter into so-called professional contracts and properly tax an athlete's income. Financial administrative authorities, however, would have to properly apply legal norms to an individual athlete's income, as well as ignore very inaccurate, and with regard to the content of the ruling, misleading, legal sentence II. from the ruling of the Supreme Administrative Court, stating that from 'a tax point of view, an athlete may be considered as a self-employed person'. Yes, an athlete may, in the Czech Republic, be considered from a tax perspective as a self-employed person, but not in the case of team players who receive fees from their clubs. Our initial hypothesis, that the activity of team players should be taxed under the income from self-employment, has been partially confirmed regarding income from sponsors, however it was proved false in regards to income from clubs.

\section{References}

1. The article comes out of the results of a project 'Vybrané aspekty prímých daní a jejich interpretace a aplikace $\mathrm{v}$ judikature' number MUNI/A/0856/2013, funded by the specific research of Masaryk University, which were published in a monograph Michal Radvan, Petr Mrkývka, Jana Kranecová, Michal Janovec \& Martina Valachová, Vybrané aspekty prímých daní a jejich interpretace a aplikace v judikatuře (1st ed., Iuridica. Editio Scientia no. 503, Brno, Masarykova univerzita, 2014). 
2. Ruling of the Supreme Administrative Court, Nov. 29, 2011, case no. 2 Afs 16/2011-78.

3. Tomás Sluka, Profesionální sportovec: právní a ekonomické aspekty (Praha, Havlíček Brain Team, 2007).

4. Karolina Tetlak, Taxation of International Sportsmen (Amsterdam, IBFD, 2014).

5. Alan Simpson, Taxation of Non-Resident Entertainers and Sportsmen: The United Kingdom's Definition of Performance Income and How it Ought to be Measured, Washington University Global Studies Law Review, 693, http://openscholarship.wustl.edu/law globalstudies/vol11/iss 3/5. (accessed 10 July 2014).

6. Walter Loukota, Markus C. Stefaner (eds.), Taxation of Artistes and Sportsmen in International Tax Law (Vienna, Linde Verlag, 2007).

7. Let's disregard team competitions in team sports - for example Davis Cup, Fed Cup, European Championships of Teams in Athletics.

8. A similar situation in the Slovak Republic is mentioned by for example Čollák. See Jaroslav Čollák, Profesionálna športová činnost: súčasnost' a možné trendy jej vývoja, vol. 63, no. 10, Justičná revue, 1400-1409 (2011).

9. Art. 1746 par. 2 Act no. 89/2012 Col. Civil Code as amended, resp. Art. 51 Act no. 40/1964 Col. Civil Code as amended in case of contracts concluded before 2014.

10. Fotbal.cz, eSports.cz, s.r.o, Directive on the evidence of professional and non-amateur contracts, http://nv.fotbal.cz/ftp/cmfs/legislativa/stanovy/07 Smernice pro evidenci $s$ mluv 2.doc (accessed 10 July 2014).

11. Tomáš Sluka, Profesionální sportovec: právní a ekonomické aspekty, 123-130 (Praha, Havlíček Brain Team, 2007). Roman Vybíral, Analýza judikatury vztahující se $\mathrm{k}$ postavení profesionálních sportovců $\mathrm{v}$ oblasti kolektivních sportů v České republice, vol. 22, no. 1, Jurisprudence, 13 (2013).

12. Act no. 586/1992 Col. on income taxes, as amended. 
13. Jiř́ Sabou, ex-player of Zizkov and Teplice, stated among his costs a fee for his agent who was supposed to negotiate contracts for him in Manchester United, FC Barcelona, Olympique Marseille or AC Monaco even though none of these teams knew nothing about this average Czech football player. This whole matter was addressed by the European Court of Justice in Luxembourg. See Ruling of the ECJ, Oct. 22, 2013, case no. C-276/12 - Jiri Sebou v. Financial Directorate Prague. http://curia.europa.eu/ (accessed 29 November 2013). Also Aktualne.cz, Tomáš Fránek, Š́fa Manchesteru se ptali na nízké daně českého fotbalisty, http://sport.aktualne.cz/sefamanchesteru-se-ptali-na-nizke-dane-ceskehofotbalisty/r-ad5e7aa0c44411e2a2010025.900fea04/ (accessed 10 July 2014). 14. According to effective legal norms, it is possible to prolong an employment agreement only twice, shall it be prolonged one more time, the employment contract must be concluded for indefinite time.

15. Act no. 455/1991 Col. Trade Licensing Act, as amended.

16. Ruling of the Supreme Administrative Court, Nov. 29, 2011, case no. 2 Afs 16/2011-78, in this case, the court examined the activity of a professional hockey player and concluded that 'the activity of a professional athlete cannot be easily subordinated under "employment" in the sense of the Labor Act'. It cannot be therefore excluded, resp. considered illegal the conclusion of other than labor contracts between players and their clubs. It is disputable, whether it is necessary to interpret the term 'employment' and forget to deal with the similar but tax term 'employment'. This simplification then leads to a faulty conclusion of the court, which states: '... it is generally accepted in practice that professional athlete may - from a tax point of view - act as self-employed ... To divert from this generally accepted practice, there would have to exist a very strong reason based on for example an explicit change of the legal norms. Otherwise it is possible to argue by way of certain level of normative power of facticity.' However this conclusion is wrong because the fact that something is happening illegally for a longer period of time cannot mean that this behavior shall become in accordance with the law.

17. See ruling of the Supreme Administrative Court, June 1, 2005, case no. 2 Afs 176/2004-140. 
18. Tomáš Sluka, Profesionální sportovec: právní a ekonomické aspekty, 123-130 (Praha, Havlíček Brain Team, 2007). Roman Vybíral, Analýza judikatury vztahující se $\mathrm{k}$ postavení profesionálních sportovců $\mathrm{v}$ oblasti kolektivních sportů v České republice, vol. 22, no. 1, Jurisprudence, 13 (2013).

19. Ruling of the Supreme Administrative Court, Feb. 24, 2005, case no. 2 Afs 62/2004-70.

20. Art. 6 of the Income Tax Act.

21. Ruling of the Supreme Administrative Court, Nov. 29, 2011, case no. 2 Afs 16/20011-78.

22. Comp. Alan Simpson, Taxation of Non-Resident Entertainers and Sportsmen: The United Kingdom's Definition of Performance Income and How it Ought to be Measured, no 11, Washington University Global Studies Law Review, 693, http://openscholarship.wustl.edu/law globalstudies/vol11/iss $3 / 5$. (accessed 10 July 2014).

23. Karolina Tetlak, Taxation of International Sportsmen, 11-17 (Amsterdam, IBFD, 2014).

24. Aktualne.cz, Luděk Mádl, Čeští páni fotbalisti, pozor! Platini vám provětrá peněženky, http://sport.aktualne.cz/cesti-pani-fotbalisti-pozorplatini-vam-provetra-penezenky/r $\mathrm{r}$ cbfd0fe2e7f511e2ac070025.90604f2el (accessed 10 July 2014).

25. Aktualne.cz, Messi se vyplatí. 15 milionů eur jej zachrání před soudem, http://sport.aktualne.cz/messi-se-vy.plati-15-milionu-eur-jej-zachrani-predsoudem/r-e29625f4df4e11e285180025.90604f2el (accessed 10 July 2014). 